\title{
Adult hippocampal neurogenesis and its role in Alzheimer's disease
}

\author{
Yangling $\mathrm{Mu}^{*}$ and Fred $\mathrm{H}$ Gage
}

\begin{abstract}
The hippocampus, a brain area critical for learning and memory, is especially vulnerable to damage at early stages of Alzheimer's disease (AD). Emerging evidence has indicated that altered neurogenesis in the adult hippocampus represents an early critical event in the course of AD. Although causal links have not been established, a variety of key molecules involved in AD pathogenesis have been shown to impact new neuron generation, either positively or negatively. From a functional point of view, hippocampal neurogenesis plays an important role in structural plasticity and network maintenance. Therefore, dysfunctional neurogenesis resulting from early subtle disease manifestations may in turn exacerbate neuronal vulnerability to AD and contribute to memory impairment, whereas enhanced neurogenesis may be a compensatory response and represent an endogenous brain repair mechanism. Here we review recent findings on alterations of neurogenesis associated with pathogenesis of AD, and we discuss the potential of neurogenesis-based diagnostics and therapeutic strategies for AD.
\end{abstract}

Keywords: Alzheimer's disease, adult neurogenesis, hippocampus, neural stem cell

\section{Introduction}

Alzheimer's disease (AD), first described by the German neuropathologist Alois Alzheimer as Dementia Praecox in 1907, is an age-related neurodegenerative disease characterized by progressive loss of memory and deterioration of cognitive functions. Individuals with the disorder usually experience difficulties in learning, performance speed, recall accuracy and/or problem solving [1]. The gradual intraneuronal accumulation of neurofibrillary tangles formed as a result of abnormal hyperphosphorylation of cytoskeletal tau protein, extracellular deposition of amyloid- $\beta$ (A $\beta$ ) protein as senile plaques, and massive neuronal death represent important neuropathological hallmarks of AD [2]. These pathologies are evident in specific, vulnerable brain areas and the hippocampus is one of the earliest to be affected [3]. The hippocampus is a mammalian brain structure that lies under the medial temporal lobe, with one on each side of the brain. Although there is a lack of consensus relating to terms describing the hippocampus and its adjacent cortex, the term hippocampus or hippocampal formation generally applies to the dentate

\footnotetext{
* Correspondence: ymu@salk.edu

Laboratory of Genetics, the Salk Institute for Biological Studies, La Jolla, CA
} 92037, USA gyrus (DG), the hippocampus proper - composed of CA1, CA2 and CA3 fields - and the subiculum. The organization of the hippocampal circuitry has been traditionally characterized as a unidirectional, trisynaptic excitatory pathway (reviewed in [4]). Briefly, the entorhinal cortex (EC) provides the main source of input to the hippocampus through connections to the DG. Information flow then proceeds from DG to CA3 to CA1. In turn, CA1 projects to the subiculum and sends the hippocampal output back to the deep layers of EC. Behavioral studies have long suggested that the hippocampus plays a critical role in learning and memory [5], which depend on functional and structural changes occurring in the hippocampus, such as long-term potentiation (LTP) and synaptic remodeling [6,7]. The discovery of a de novo production of neurons in the adult DG has introduced the possibility of a new form of plasticity that could sustain memory processes. A growing body of evidence supports the view that promotion of adult hippocampal neurogenesis improves pattern separation and spatial memory $[8,9]$. In contrast, a decline in neurogenesis may underlie cognitive impairments associated with aging and disorders such as $\mathrm{AD}[10,11]$. Interestingly, increasing evidence shows that central molecular players in $A D$ influence the generation of new
C Biomed Central

() 2011 Mu and Gage; licensee BioMed Central Ltd. This is an Open Access article distributed under the terms of the Creative Commons Attribution License (http://creativecommons.org/licenses/by/2.0), which permits unrestricted use, distribution, and reproduction in any medium, provided the original work is properly cited. 
hippocampal neurons, and noteworthy alterations in neurogenesis take place earlier than the onset of hallmark lesions or neuronal loss [12]. Although seemingly contradictory results have been reported in both murine and human studies [13], preserving or potentiating the production of new neurons has been regarded as a potential therapeutic strategy to delay or halt AD-linked cognitive decline. Furthermore, understanding the mechanisms of changes in neurogenesis observed at initial and later stages of AD will contribute to the development of early AD biomarkers and reveal insights into the pathogenesis of AD. In this manuscript, we will summarize current knowledge of the neurogenic roles of molecules whose mutations cause AD, and we will discuss the potential application of newly generated hippocampal neurons in the diagnosis and treatment of AD.

\section{Neurogenesis in the adult hippocampus}

Continual production of new neurons in the adult hippocampus was first reported by Altman and colleagues [14]. These new neurons originate from self-renewing and multipotent adult neural stem cells (NSCs) residing in the subgranular zone (SGZ) of DG [15]. Two types of NSCs have been identified based on their specific morphologies, proliferative behaviors and expression of unique sets of molecular markers (reviewed in [16]). Type 1 neural progenitor cells (NPCs) have a radial process spanning the entire granule cell layer and ramifying in the inner molecular layer of DG. They are generally identified by specific molecular markers such as GFAP, Sox 2 and Nestin. These cells have been hypothesized to be the quiescent stem cells that generate the second type of NSC, the actively self-amplifying, nonradial type 2 cells. These intermediate cells, expressing Sox2, Nestin but not GFAP, subsequently give rise to DCX+ neuroblasts that differentiate into glutamatergic dentate granule cells (DGCs) populating the inner third of the granule cell layer. Young adult rats generate approximately 9,000 new cells in the SGZ each day, with a survival rate of $\sim 50 \%$ [17]. The surviving cells send dendrites to the molecular layer of DG to receive inputs from the EC and send axonal projections to the CA3 subfield of the hippocampus to innervate hilar interneurons, mossy cells and CA3 pyramidal cells (Figure 1 ), thereby integrating into existing neuronal circuits $[18,19]$. The process of new neuron generation and incorporation involves multiple crucial steps. Many layers of regulation, composed of both intrinsic and

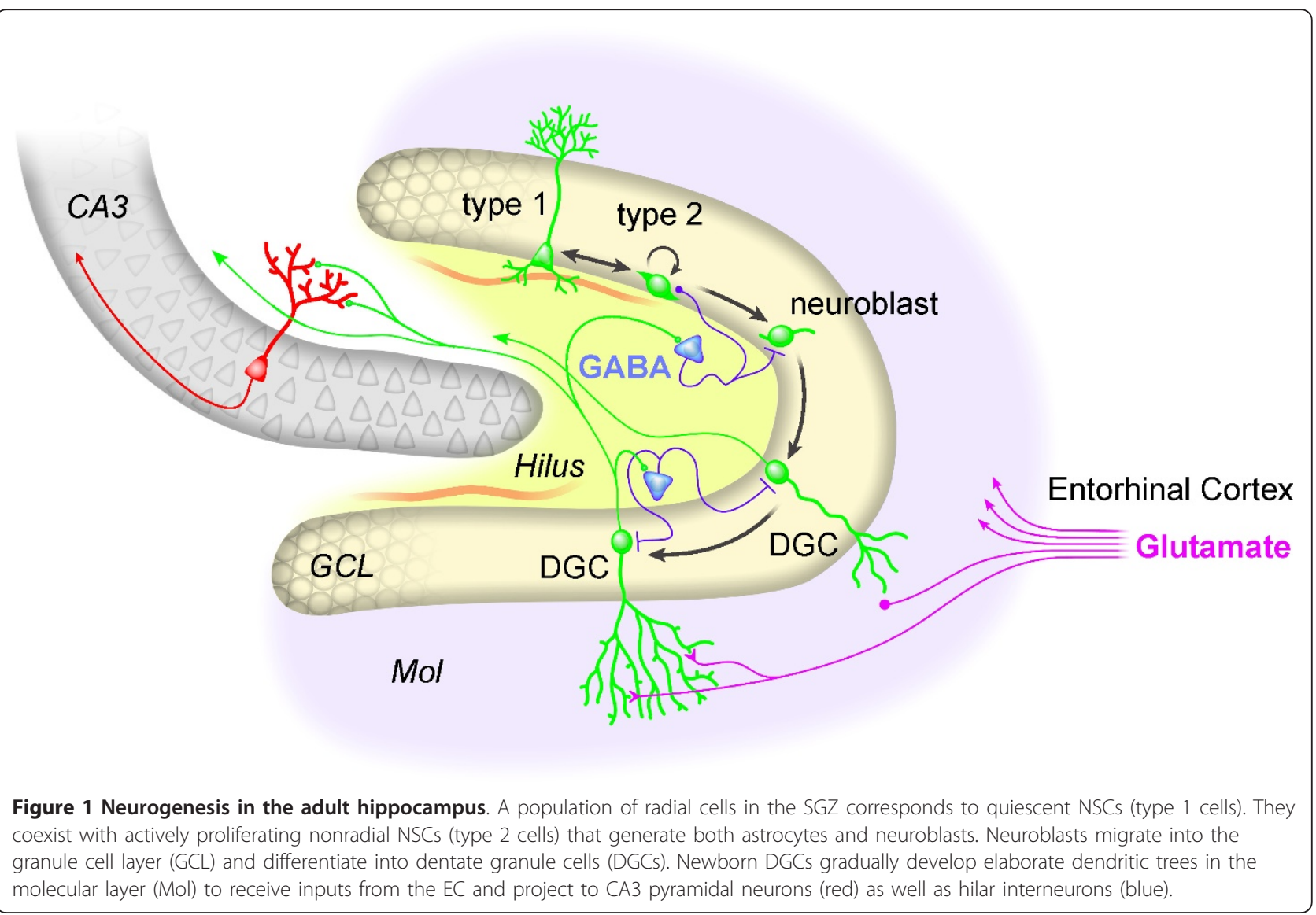


extrinsic mechanisms, have been identified for each step. For example, a number of morphogens that are critical during embryonic development of the nervous system, including Notch, Shh, Wnts, and BMPs, are conserved and continue to serve as niche signals to regulate maintenance, activation, and fate choice of adult NSCs. Various neurotransmitter systems, growth factors, neurotrophins, cytokines, and hormones are also major regulators of different phases of adult neurogenesis. Additionally, intrinsic factors such as miRNAs, transcription factors, cell-cycle regulators, and epigenetic factors exhibit cell-autonomous characteristics that provide adult NSCs with the potential to proliferate, differentiate, and survive as newborn neurons. Comprehensive reviews on this subject can be found elsewhere [16,20].

During maturation, newly formed DGCs differ substantially from their older, neighboring counterparts in terms of electrophysiological properties. Typically, they exhibit enhanced synaptic plasticity with both increased amplitude and decreased induction threshold for LTP [21-24]. While the precise functional implications of the continuous production of new neurons with hyperexcitability and enhanced synaptic plasticity are still under intense investigation, it has become increasingly apparent that neurogenesis in the adult DG contributes to various types of hippocampus-dependent learning and memory. The first definitive evidence was provided by the demonstration that a substantial reduction in the number of newly generated DGCs by an antimitotic agent MAM disrupted trace eye-blink conditioning and trace fear conditioning, both of which are regarded to be hippocampus-dependent [25]. A number of subsequent studies utilizing irradiation or genetic modification to eliminate adult neurogenesis in rodent models also observed impaired performance in spatial-navigation learning and long-term spatial memory retention, spatial pattern discrimination, trace conditioning and contextual fear conditioning, clearance of hippocampal memory traces, and reorganization of memory to extrahippocampal substrates (reviewed in [26,27]). Conversely, genetic manipulation and deep brain stimulation that boost neurogenesis have been shown to facilitate pattern separation and water-maze memory, respectively $[8,9]$. With a combination of theoretical and experimental approaches at cellular, network and system levels, future studies will clarify how addition of a relatively small number of new neurons can modulate global hippocampal or brain function.

\section{Neurogenesis deficits in AD mouse models}

As described in the introduction, senile plaques, a neuropathological hallmark of $\mathrm{AD}$, are made up largely of 38-43 amino acid $\beta$-amyloid peptides $(A \beta)$, which are liberated from a larger integral membrane protein, amyloid precursor protein (APP), by sequential $\beta$ - and $\gamma$ secretase cleavage [2]. Several lines of evidence support the hypothesis that $A \beta$ is a key trigger of $A D$ pathogenesis [28]. The vast majority of $\mathrm{AD}$ cases appear in lateonset sporadic form. While aging is the greatest environmental risk factor of the sporadic form, the presence of the $\varepsilon 4$ allele in apolipoprotein E (ApoE4) represents the most important genetic risk factor [29]. Rare, familial, early-onset autosomal dominant forms of AD (FAD) are found to involve mutations in the genes encoding APP and presenilins (PS1 and PS2). Presenilins form the catalytic core of the aspartyl protease $\gamma$-secretase complex responsible for intramembranous processing of a variety of type I membrane proteins, including APP. Cleavage of APP at the $\mathrm{N}$-terminus by $\beta$-secretase and at the C-terminus by the $\gamma$-secretase complex constitutes the amyloidogenic pathway, which yields the APP intracellular domain (AICD) fragment in addition to $A \beta$. In the non-amyloidogenic pathway, $\alpha$-secretase cleaves $\mathrm{APP}$ within the $\mathrm{A} \beta$ domain, which results in generation of a soluble fragment of APP ( $\mathrm{APP} \alpha)$ and a membranebound carboxyl-terminal fragment, thereby precluding the formation of $A \beta$ (Figure 2). Strikingly, quite a few molecules central to AD have been found to play a regulatory role in aspects of adult neurogenesis. Using a loss-of-function animal model by crossing ApoE-deficient mice to a nestin-GFP reporter, Yang et al. demonstrated that lack of ApoE increased proliferation of early NPCs within the DG, which resulted in depletion of the overall pool of Type 1 NPCs over time [30]. A recent study showed that NPCs infected with lentiviral vectors expressing short interfering RNA (siRNA) for the exclusive knockdown of PS1 in the neurogenic microenvironments exhibited a dramatic enhancement of cell differentiation in a $\gamma$-secretase-dependent manner [31]. BrdU incorporation assay has shown that AICD expression decreased hippocampal progenitor cell proliferation and survival [32]. In contrast to the negative effect of AICD on neurogenesis, the SAPP $\alpha$ was shown to protect neurons and promote neurogenesis, possibly mediated by its ability to prevent overactivation of CDK5 and tau hyperphosphorylation [33]. For instance, sAPP $\alpha$ regulated proliferation of EGF-responsive NPCs in the subventricular zone (SVZ) of the lateral ventricle, the other neurogenic area of the adult brain [34]. Although it was suggested that the effect of $\mathrm{SAPP} \alpha$ was limited in the SVZ, due to the absence of sAPP $\alpha$-binding sites in the SGZ [34], this conclusion contrasts with the observation that deficiency of the sortilin-related receptor with typeA repeats resulted in increased proliferation and survival of NPCs in both the SVZ and the DG, most likely as a consequence of an enhancement of local sAPP $\alpha$ production [35]. Information from studies using gene-modified 


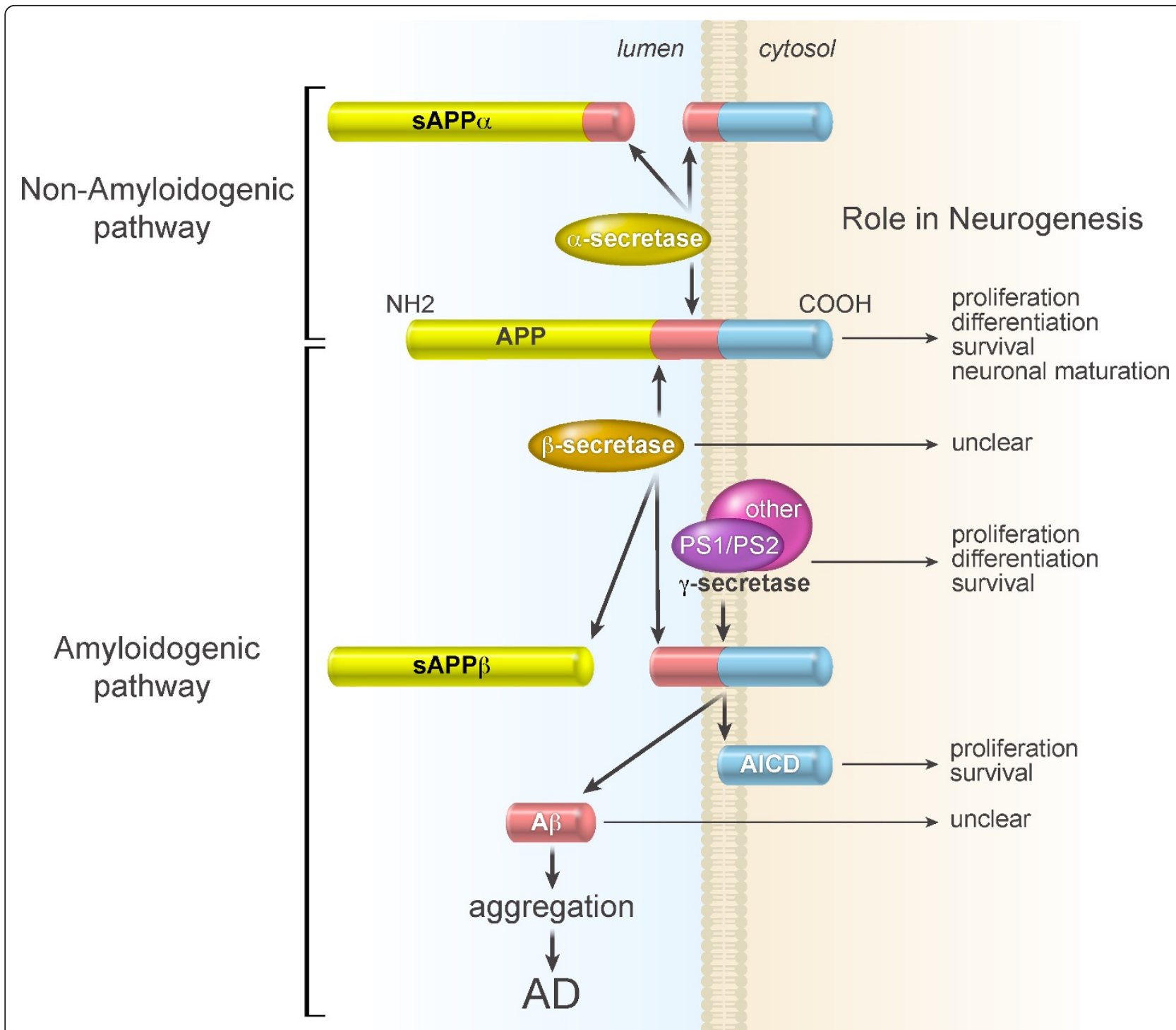

Figure 2 Molecular basis for AD and interaction with neurogenesis in the adult hippocampus. In the non-amyloidogenic pathway, APP is processed by $\alpha$-secretase that cleaves within the A $\beta$ domain. SAPP $\alpha$ and a membrane-bound carboxyl-terminal fragment are generated. In the amyloidogenic pathway, APP is sequentially cleaved by $\beta$ - and $\gamma$-secretases to release the neurotoxic A $\beta$ peptide. $\beta$-secretase cleavage of APP forms a secreted ectodomain SAPP $\beta$ and a membrane-bound fragment. Cleavage of the latter product generates AICD and A $\beta$. Suggested functions of relevant signal molecules in adult hippocampal neurogenesis are summarized.

mouse models of $\mathrm{AD}$ seems to be more complex (Table 1). Mutations of PS1 generally have a negative effect on the production of new neurons, although the dependency of $\gamma$-secretase remains to be confirmed. Using PS1M146V knock-in mice in which the M146V mutation is incorporated into the endogenous mouse PS1 gene, Wang et al. reported that the FAD mutation impaired contextual fear conditioning, which is correlated with reduced adult neurogenesis in the DG [36]. Expression of human mutant PS1P117L in transgenic mice decreased the survival of BrdU-labeled NPCs, thereby leading to fewer new $\beta$-III-tubulin- immunoreactive neurons being generated in FAD mutant animals during the 4-week postlabeling period [37]. Enriched environment (EE)-induced proliferation and neuronal differentiation of hippocampal progenitor cells in mice harboring transgenes encoding the FADlinked human PS1 variant PS1 $\triangle \mathrm{E} 9$ or PS1M146L were significantly impaired, although the impairment was at least in part mediated by soluble factors released from microglia, thus indicating a non-cell-autonomous mechanism underlying PS1 regulation of adult hippocampal neurogenesis [38]. Similarly, the proliferation and survival of NPC were reduced in transgenic mice 
Table 1 Summary of neurogenesis changes in transgenic mouse models of AD

\begin{tabular}{|c|c|c|c|c|c|c|c|c|}
\hline $\begin{array}{l}\text { Genetic } \\
\text { Manipulation }\end{array}$ & $\begin{array}{l}\text { Strain } \\
\text { Name }\end{array}$ & Genotype & Promoter & $\begin{array}{l}\text { Age } \\
\text { (mon) }\end{array}$ & $\begin{array}{l}\text { Pathology } \\
\text { (A } \beta \\
\text { deposition) }\end{array}$ & $\begin{array}{l}\text { Neurogenesis } \\
\text { assessment }\end{array}$ & Effect & Reference \\
\hline \multirow[t]{3}{*}{ Knock-in } & & $\begin{array}{l}\text { mo } \\
\text { PS1M146V/- }\end{array}$ & & 3 & & $\begin{array}{l}\text { BrdU injection twice } \\
\text { daily ( } 2 \text { hr apart) for } 4 \\
\text { consecutive days }\end{array}$ & $\begin{array}{l}\text { Decreased proliferation and } \\
\text { differentiation }\end{array}$ & [36] \\
\hline & & hu ApoE4 & & $\begin{array}{l}3,6-7 \\
12-13\end{array}$ & & $\begin{array}{l}\text { BrdU injection twice (6 } \\
\text { hr apart) }\end{array}$ & Diminished neuronal maturation & [41] \\
\hline & & $\begin{array}{l}\text { mo APPswe/ } \\
\text { PS1 } \triangle \text { E9 }\end{array}$ & & $\begin{array}{l}8-9 \\
18-24\end{array}$ & post & $\begin{array}{l}\text { DCX, MCM2 } \\
\text { immunostaining }\end{array}$ & Decreased proliferation & [42] \\
\hline \multirow[t]{10}{*}{ Transgenic } & & hu PS1P117L & NSE & $3-4$ & & $\begin{array}{l}\text { one BrdU injection per } \\
\text { day for } 12 \text { consecutive } \\
\text { days }\end{array}$ & Decreased survival & {$[37]$} \\
\hline & & $\begin{array}{l}\text { hu PS1 } \triangle E 9, \\
\text { hu PS1M146L }\end{array}$ & $\operatorname{PrP}$ & 3 & & $\begin{array}{l}\text { single injection of } \\
\text { BrdU }\end{array}$ & $\begin{array}{l}\text { Decreased proliferation and } \\
\text { differentiation }\end{array}$ & [38] \\
\hline & $\operatorname{Tg} 2576$ & $\begin{array}{l}\text { chimeric mo- } \\
\text { hu APPswe }\end{array}$ & $\operatorname{PrP}$ & $12-14$ & pre & $\begin{array}{l}\text { five daily injections of } \\
\text { BrdU }\end{array}$ & $\begin{array}{l}\text { Decreased proliferation, survival and } \\
\text { differentiation }\end{array}$ & [39] \\
\hline & PDAPP & hu APPind & PDGF & $\begin{array}{l}2 \\
12\end{array}$ & $\begin{array}{l}\text { pre } \\
\text { post }\end{array}$ & $\begin{array}{l}\text { one i.p. injection of } \\
\text { BrdU }\end{array}$ & Decreased proliferation and survival & [40] \\
\hline & $\begin{array}{l}\text { APP/ } \\
\text { PS1 }\end{array}$ & $\begin{array}{l}\text { chimeric mo- } \\
\text { hu APPswe/ } \\
\text { hu PS1 } 1 \text { E9 }\end{array}$ & PrP & 6 & pre, post & $\begin{array}{l}\text { BrdU injection once } \\
\text { daily for } 12 \\
\text { consecutive days }\end{array}$ & Decreased survival & [43] \\
\hline & $\begin{array}{l}\text { APP/ } \\
\text { PS1 }\end{array}$ & $\begin{array}{l}\text { chimeric mo- } \\
\text { hu APPswe/ } \\
\text { hu PS1 } 1 \text { E9 }\end{array}$ & $\operatorname{PrP}$ & 2 & pre & $\begin{array}{l}\text { BrdU injection every } \\
12 \mathrm{hr} \text { for } 3 \text { days }\end{array}$ & $\begin{array}{l}\text { Decreased proliferation and } \\
\text { differentiation }\end{array}$ & [44] \\
\hline & $\begin{array}{l}3 \times \operatorname{Tg}- \\
A D\end{array}$ & $\begin{array}{l}\text { hu APPswe/ } \\
\text { PS1M146V/ } \\
\text { tauP301L }\end{array}$ & Thy -1.2 & 4,9 & & & Decreased proliferation & [45] \\
\hline & $J 20$ & $\begin{array}{l}\text { hu APPswe, } \\
\text { ind }\end{array}$ & PDGF & 3,12 & pre, post & $\begin{array}{l}\text { BrdU injection twice } \\
\text { daily ( } 8 \text { hr apart) for } 3 \\
\text { consecutive days }\end{array}$ & $\begin{array}{l}\text { Increased proliferation and } \\
\text { differentiation }\end{array}$ & [46] \\
\hline & $J 20$ & $\begin{array}{l}\text { hu APPswe, } \\
\text { ind }\end{array}$ & PDGF & $\begin{array}{l}3,5 \\
9,11\end{array}$ & pre, post & $\begin{array}{l}\text { daily injection of BrdU } \\
\text { for } 5 \text { days }\end{array}$ & $\begin{array}{l}\text { Increased proliferation and } \\
\text { differentiation }\end{array}$ & [47] \\
\hline & $J 20$ & $\begin{array}{l}\text { hu APPswe, } \\
\text { ind }\end{array}$ & PDGF & $2-3$ & pre & $\begin{array}{l}\text { BrdU injection for } 3 \\
\text { days }\end{array}$ & $\begin{array}{l}\text { Accelarated early development but } \\
\text { impaired late maturation of newborn } \\
\text { neurons }\end{array}$ & [48] \\
\hline \multirow[t]{2}{*}{ Knock-out } & & ApoE & & $\begin{array}{l}3,6-7 \\
12-13\end{array}$ & & $\begin{array}{l}\text { BrdU injection twice (6 } \\
\text { hr apart) }\end{array}$ & $\begin{array}{l}\text { Reduced neurogenesis but increased } \\
\text { astrogenesis }\end{array}$ & [41] \\
\hline & & $\begin{array}{l}\text { PS1/PS2 } \\
\text { forebrain KO }\end{array}$ & & $\begin{array}{l}7-9 \\
18-20\end{array}$ & & $\begin{array}{l}\text { single dose injection } \\
\text { of } \mathrm{BrdU}\end{array}$ & $\begin{array}{l}\text { Enhanced cell proliferation at early } \\
\text { stages of neurodegeneration but } \\
\text { impaired survival at late stages }\end{array}$ & [49] \\
\hline
\end{tabular}

expressing a chimeric mouse-human (mo-hu) APP695swe (APPswe) polypeptide, a mutated form of APP that causes early onset FAD [39]. An age-dependent decrease in SGZ proliferation was also observed in mice transgenic for human V717F mutant APP, a model of $\mathrm{AD}$ with age-dependent accumulation of $\mathrm{A} \beta_{42}$-containing plaques [40]. Furthermore, adult neurogenesis was reduced in mice with knock-out (KO) for ApoE or with knock-in (KI) alleles for human ApoE4. Increased BMP signaling promoted glial differentiation at the expense of neurogenesis in ApoE-KO mice, whereas presynaptic GABAergic input-mediated maturation of newborn neurons was diminished in ApoE4-KI mice because of decreased interneuron survival. Potentiating GABAergic signaling restored neuronal maturation and neurogenesis in ApoE4-KI mice to normal levels [41]. Several additional studies examined hippocampal neurogenesis in transgenic mice coexpressing two or three mutated genes. For example, the double knock-in mice harboring mutant APPswe/PS1 $\triangle \mathrm{E} 9$ exhibited a significant reduction in dentate neuroblasts [42]. Long-term survival of newborn neurons was dramatically diminished in transgenic mice overexpressing the Swedish variant of APP and the exon 9-deleted variant of human PS1 [43]. In particular, a significant reduction in proliferation of NPCs and neuronal differentiation was found to take place in the same transgenic mouse line long before amyloid deposition, and interestingly, hyperphosphorylation of the microtubule-associated protein tau in the neurogenic niches might underlie the impaired neurogenesis [44]. Another study was performed in the triple transgenic mice $3 x \mathrm{Tg}$-AD that harbors three mutant 
genes (APPswe, PS1M146V and tauP301L). Decreased proliferation was found in 3xTg-AD mice; this reduction was directly associated with the presence of $A \beta$ plaques and an increase in the number of $A \beta$-containing neurons in the hippocampus [45]. Despite this compelling evidence for a generalized decrease in new neuron generation in AD mouse models, conflicting observations have been reported. PDGF-APPswe, ind mice (J20), which express the Swedish and Indiana APP mutations driven by a PDGF promoter, showed increased incorporation of BrdU and expression of immature neuronal markers in the DG. These changes occurred before neuronal loss and amyloid deposition could be detected [46]. A separate study revealed an increase in not only NSC proliferation but also neuronal differentiation in J20 mice, which were induced by oligomeric $A \beta$ [47]. Additionally, adult-born DGCs in a similar animal model exhibited longer dendrites, higher spine density and stronger functional responses at an early developmental stage, but they were impaired morphologically and functionally during later maturation. Early inhibition of GABAergic signaling or late facilitation of glutamatergic signaling can normalize neuronal development despite the presence of high $A \beta$ levels, suggesting that abnormal GABAergic neurotransmission or an imbalance between GABAergic and glutamatergic neurotransmission may contribute to impaired neurogenesis in $\mathrm{AD}$ models [48]. Notably, although most studies, as described above, have demonstrated either a single compromise or a single enhancement of adult neurogenesis resulting from $\mathrm{AD}$-associated gene mutations, conditional ablation of PS1 in the forebrain and knock out of PS2 in adult mice (PS1/PS2 conditional double knockout) was found to cause neurodegenerative stage-dependent dynamic changes. Cell proliferation was significantly enhanced at early stages of neurodegeneration, whereas the survival of newly generated neurons was impaired up to late stages [49].

In summary, studies using transgenic models of $\mathrm{AD}$ over the past few years have generated mounting evidence supporting alterations in neurogenesis. Because of differences in many parameters, there are apparent discrepancies in the current literature, with a majority of studies reporting compromised neurogenesis and some others observing increased new neuron generation. Thus, a systematic comparison of transgenic mice using the same age, gender, genetic background, neuropathology stage and a similar method of neurogenic analysis (BrdU regimen, cell markers, etc.) would be necessary to draw a definite conclusion. In particular, as promoters determine the expression and neuronal populations of the transgenes, transgenic lines are likely to express distinct levels and/or patterns of AD-associated proteins. Therefore, investigation of different AD transgenic models under the same promoter will be required as well and knock-in lines are more relevant in this regard. A thorough understanding of the molecular mechanisms underlying changes in neurogenesis associated with mutations of AD-causing genes will probably be a crucial next step in understanding how they are linked to the general intrinsic and extrinsic factors that have been identified to regulate neurogenesis. In addition, although numerous studies employing diverse paradigms suggest that FAD-linked transgenic mice exhibit impairment in learning and memory (see [50] for a review), it remains unclear whether the malfunction results from decreased hippocampal neurogenesis. In PS1M146V/- mice, impaired contextual fear learning showed correlation with reduced neurogenesis in the DG, whereas both short-term and long-term synaptic plasticity in area CA1 and DG remained unaffected [36]. This observation has provided thus far the only piece of evidence directly supporting the hypothesis that impaired adult neurogenesis exacerbates memory deficits. Nevertheless, the functional implications of aberrant neurogenesis in transgenic models of AD need to be further characterized to establish the causal relationship.

The existing transgenic animal models only exhibit partial AD pathology and it is thus necessary to correlate the mouse model studies with human samples. One study that analyzed neurogenesis in postmortem human brains by Western blot and immunohistochemistry methods reported that the hippocampus of senile AD patients showed increased expression of immature neuronal marker proteins that signal the birth of new neurons, including DCX, polysialylated nerve cell adhesion molecule, neurogenic differentiation factor and TUC-4. The authors hypothesized that facilitation of neurogenesis might be a self-compensating mechanism to replace the lost neurons and that stimulating hippocampal neurogenesis might provide a new treatment strategy for AD [51]. However, immunostaining for Ki-67, GFAP and $\mathrm{DCX}$ in presenile AD cases revealed no indications of altered DG neurogenesis [52]. Moreover, A $\beta$-associated increases in BMP6 expression were found accompanied by reduced markers of neurogenesis in the hippocampus of human patients with AD [53]. Obviously, these findings are not in agreement, and the discrepancies may arise from stage of the disease, treatment provided to the patients and method for labeling proliferating cells. More systematic studies are required for further clarification.

\section{Environmental Enrichment, Neurogenesis and AD}

It has become increasingly evident that neurogenesis in the adult brain is under the influence of key molecules underlying $\mathrm{AD}$ and the alterations take place early in life. Thus, the process of new neuron addition may have 
a reciprocal connection with $\mathrm{AD}$ pathogenesis rather than be simply a result of neural dysfunction, a possibility that opens new opportunities for cellular therapy for this disease. Physical exercise or exposure to EE, a putative positive regulator of adult neurogenesis [11], improves cognitive performance in transgenic mouse models of AD [54-56]. Complex environmental experience has been reported to reduce $A \beta$ levels and amyloid deposition, rescue impaired neurogenesis, and significantly enhance hippocampal LTP in APPswe/PS1DE9 mice $[57,58]$. Both running and $\mathrm{EE}$ increase the number of newborn granule cells in the DG of APP23 mice and improve their water maze performance $[59,60]$. However, EE does not enhance neurogenesis in transgenic mice harboring FAD-linked PS1 variants [38] or in forebrain-specific PS1 knockout mice [61], and it even suppresses neurogenesis in ApoE4 transgenic mice [62]. Taken together, these studies indicate that the effects of exercise and $E E$ on adult neurogenesis vary between the mouse models of AD. Future experiments should investigate their impact on transgenic mice exhibiting different aspects of AD pathology and determine the dependence of observed behavioral improvement on rescued neurogenesis.

\section{Conclusions}

We have presented evidence that multiple molecular players known to contribute to AD pathogenesis, mainly ApoE, PS1, APP and its metabolites, can modulate adult hippocampal neurogenesis. The apparent discrepancies between increased and decreased new neuron production in studies on human and transgenic murine models might be reconciled by a thorough investigation of different NSC populations under different disease conditions. Notably, alterations in neurogenesis occur at the very early stage of $A D$ progression, prior to processes that may secondarily affect neurogenesis, such as neuronal loss, amyloid deposition and inflammation. These findings suggest that neurogenesis represents an integral part of AD pathology. On the one hand, expression of AD-causing molecules impinges upon neurogenesis and dysregulated neurogenesis might in turn facilitate disease progression. On the other hand, conditions that stimulate endogenous neurogenesis (e.g., environmental stimuli, physical activity, trophic factors, cytokines, and drugs) may help to promote the regenerative and recovery process. Although newly generated DGCs are very small in number as compared to the degenerating neurons in $\mathrm{AD}$, and therefore unlikely to achieve global repair, it is possible to slow down or prevent severe cognitive decline by eliminating initial deleterious triggers. Furthermore, as compared to classical neuropathological hallmarks of $\mathrm{AD}$, adult neurogenesis may serve as an early-stage disease model for drug testing and screening. The development of noninvasive detection of adult neurogenesis and specific biomarkers might provide new means of early diagnosis of AD.

\section{List of abbreviations used}

AB: amyloid- $\beta$; AD: Alzheimer's disease; AICD: APP intracellular domain; APP: amyloid precursor protein; BrdU: bromodeoxyuridine; DCX: doublecortin; DG: dentate gyrus; DGC: dentate granule cell; EC: entorhinal cortex; EE: enriched environment; FAD: Familial Alzheimer's disease; LTP: Iong-term potentiation; NPC: neural progenitor cell; NSC: neural stem cell; PS: presenilin; sAPPa: soluble amyloid precursor protein alpha; SGZ: subgranular zone; SVZ: subventricular zone; 3xTg-AD: triple transgenic mice.

\section{Acknowledgements}

This work was supported by McDonnell Foundation, the Ellison Medical Foundation, National Institute of Aging and the Lookout Foundation. The authors would like to thank M.L. Gage for editorial comments and J. Simon for assistance with the figures.

\section{Authors' contributions}

Manuscript drafted by YM and edited by FHG. All authors read and approved the final manuscript.

\section{Competing interests}

The authors declare that they have no competing interests.

Received: 23 November 2011 Accepted: 22 December 2011 Published: 22 December 2011

\section{References}

1. Goedert M, Spillantini MG: A century of Alzheimer's disease. Science 2006, 314:777-781.

2. Selkoe DJ: Alzheimer's disease: genes, proteins, and therapy. Physiol Rev 2001, 81:741-766.

3. Braak H, Braak E, Bohl J: Staging of Alzheimer-related cortical destruction. Eur Neurol 1993, 33:403-408.

4. Li Y, Mu Y, Gage FH: Development of neural circuits in the adult hippocampus. Curr Top Dev Biol 2009, 87:149-174.

5. Squire LR: Memory and the hippocampus: a synthesis from findings with rats, monkeys, and humans. Psychol Rev 1992, 99:195-231.

6. Bliss TV, Lomo T: Long-lasting potentiation of synaptic transmission in the dentate area of the anaesthetized rabbit following stimulation of the perforant path. J Physiol 1973, 232:331-356.

7. Matsuzaki M, Honkura N, Ellis-Davies GC, Kasai H: Structural basis of longterm potentiation in single dendritic spines. Nature 2004, 429:761-766.

8. Sahay A, Scobie KN, Hill AS, O'Carroll CM, Kheirbek MA, Burghardt NS, Fenton AA, Dranovsky A, Hen R: Increasing adult hippocampal neurogenesis is sufficient to improve pattern separation. Nature 2011, 472:466-470

9. Stone SS, Teixeira CM, Devito LM, Zaslavsky K, Josselyn SA, Lozano AM, Frankland PW: Stimulation of entorhinal cortex promotes adult neurogenesis and facilitates spatial memory. J Neurosci 2011, 31:13469-13484.

10. Clelland CD, Choi M, Romberg C, Clemenson GD Jr, Fragniere A, Tyers $P$, Jessberger S, Saksida LM, Barker RA, Gage FH, et al: A functional role for adult hippocampal neurogenesis in spatial pattern separation. Science 2009, 325:210-213.

11. Lazarov O, Mattson MP, Peterson DA, Pimplikar SW, van Praag H: When neurogenesis encounters aging and disease. Trends Neurosci 2010, 33:569-579.

12. Lazarov O, Marr RA: Neurogenesis and Alzheimer's disease: at the crossroads. Exp Neurol 2010, 223:267-281.

13. Winner B, Kohl Z, Gage FH: Neurodegenerative disease and adult neurogenesis. Eur J Neurosci 2011, 33:1139-1151.

14. Altman J, Das GD: Autoradiographic and histological evidence of postnatal hippocampal neurogenesis in rats. J Comp Neurol 1965, 124:319-335. 
15. Bonaguidi MA, Wheeler MA, Shapiro JS, Stadel RP, Sun GJ, Ming GL, Song $\mathrm{H}$ : In vivo clonal analysis reveals self-renewing and multipotent adult neural stem cell characteristics. Cell 2011, 145:1142-1155.

16. $\mathrm{Mu}$ Y, Lee SW, Gage FH: Signaling in adult neurogenesis. Curr Opin Neurobiol 2010, 20:416-423.

17. Cameron HA, McKay RD: Adult neurogenesis produces a large pool of new granule cells in the dentate gyrus. J Comp Neurol 2001, 435:406-417.

18. van Praag H, Schinder AF, Christie BR, Toni N, Palmer TD, Gage FH: Functional neurogenesis in the adult hippocampus. Nature 2002, 415:1030-1034.

19. Toni N, Teng EM, Bushong EA, Aimone JB, Zhao C, Consiglio A, van Praag H, Martone ME, Ellisman MH, Gage FH: Synapse formation on neurons born in the adult hippocampus. Nat Neurosci 2007, 10:727-734.

20. Ming GL, Song $\mathrm{H}$ : Adult neurogenesis in the mammalian brain: significant answers and significant questions. Neuron 2011, 70:687-702.

21. Schmidt-Hieber $C$, Jonas P, Bischofberger J: Enhanced synaptic plasticity in newly generated granule cells of the adult hippocampus. Nature 2004, 429:184-187.

22. Wang S, Scott BW, Wojtowicz JM: Heterogenous properties of dentate granule neurons in the adult rat. J Neurobiol 2000, 42:248-257.

23. Snyder JS, Kee N, Wojtowicz JM: Effects of adult neurogenesis on synaptic plasticity in the rat dentate gyrus. J Neurophysiol 2001, 85:2423-2431.

24. Ge S, Yang $\mathrm{CH}$, Hsu KS, Ming GL, Song H: A critical period for enhanced synaptic plasticity in newly generated neurons of the adult brain. Neuron 2007, 54:559-566.

25. Shors TJ, Miesegaes G, Beylin A, Zhao M, Rydel T, Gould E: Neurogenesis in the adult is involved in the formation of trace memories. Nature 2001, 410:372-376

26. Deng W, Aimone JB, Gage FH: New neurons and new memories: how does adult hippocampal neurogenesis affect learning and memory? Nat Rev Neurosci 2010, 11:339-350.

27. Aimone JB, Deng W, Gage FH: Resolving new memories: a critical look at the dentate gyrus, adult neurogenesis, and pattern separation. Neuron 2011, 70:589-596.

28. Hardy J, Selkoe DJ: The amyloid hypothesis of Alzheimer's disease: progress and problems on the road to therapeutics. Science 2002 297:353-356.

29. Bu G: Apolipoprotein E and its receptors in Alzheimer's disease: pathways, pathogenesis and therapy. Nat Rev Neurosci 2009, 10:333-344.

30. Yang $C P$, Gilley JA, Zhang G, Kernie SG: ApoE is required for maintenance of the dentate gyrus neural progenitor pool. Development 2011, 138:4351-4362.

31. Gadadhar A, Marr R, Lazarov O: Presenilin-1 regulates neural progenitor cell differentiation in the adult brain. J Neurosci 2011, 31:2615-2623.

32. Ghosal K, Stathopoulos A, Pimplikar SW: APP intracellular domain impairs adult neurogenesis in transgenic mice by inducing neuroinflammation. PLoS One 2010, 5:e11866.

33. Han P, Dou F, Li F, Zhang X, Zhang YW, Zheng H, Lipton SA, Xu H, Liao FF: Suppression of cyclin-dependent kinase 5 activation by amyloid precursor protein: a novel excitoprotective mechanism involving modulation of tau phosphorylation. J Neurosci 2005, 25:11542-11552.

34. Caille I, Allinquant B, Dupont E, Bouillot C, Langer A, Muller U, Prochiantz A: Soluble form of amyloid precursor protein regulates proliferation of progenitors in the adult subventricular zone. Development 2004, 131:2173-2181.

35. Rohe M, Carlo AS, Breyhan H, Sporbert A, Militz D, Schmidt V, Wozny C, Harmeier A, Erdmann B, Bales KR, et al: Sortilin-related receptor with Atype repeats (SORLA) affects the amyloid precursor protein-dependent stimulation of ERK signaling and adult neurogenesis. J Biol Chem 2008, 283:14826-14834.

36. Wang R, Dineley KT, Sweatt JD, Zheng H: Presenilin 1 familial Alzheimer's disease mutation leads to defective associative learning and impaired adult neurogenesis. Neuroscience 2004, 126:305-312.

37. Wen PH, Hof PR, Chen X, Gluck K, Austin G, Younkin SG, Younkin LH, DeGasperi R, Gama Sosa MA, Robakis NK, et al: The presenilin-1 familial Alzheimer disease mutant P117L impairs neurogenesis in the hippocampus of adult mice. Exp Neurol 2004, 188:224-237.

38. Choi SH, Veeraraghavalu K, Lazarov O, Marler S, Ransohoff RM, Ramirez JM, Sisodia SS: Non-cell-autonomous effects of presenilin 1 variants on enrichment-mediated hippocampal progenitor cell proliferation and differentiation. Neuron 2008, 59:568-580.
39. Haughey NJ, Nath A, Chan SL, Borchard AC, Rao MS, Mattson MP: Disruption of neurogenesis by amyloid beta-peptide, and perturbed neural progenitor cell homeostasis, in models of Alzheimer's disease. $J$ Neurochem 2002, 83:1509-1524.

40. Donovan MH, Yazdani U, Norris RD, Games D, German DC, Eisch AJ: Decreased adult hippocampal neurogenesis in the PDAPP mouse model of Alzheimer's disease. J Comp Neurol 2006, 495:70-83.

41. Li G, Bien-Ly N, Andrews-Zwilling Y, Xu Q, Bernardo A, Ring K, Halabisky B, Deng C, Mahley RW, Huang Y: GABAergic interneuron dysfunction impairs hippocampal neurogenesis in adult apolipoprotein E4 knockin mice. Cell Stem Cell 2009, 5:634-645.

42. Zhang C, McNeil E, Dressler L, Siman R: Long-lasting impairment in hippocampal neurogenesis associated with amyloid deposition in a knock-in mouse model of familial Alzheimer's disease. Exp Neurol 2007, 204:77-87.

43. Verret L, Jankowsky $\mathrm{L}, \mathrm{Xu} G \mathrm{G}$, Borchelt DR, Rampon C: Alzheimer's-type amyloidosis in transgenic mice impairs survival of newborn neurons derived from adult hippocampal neurogenesis. J Neurosci 2007, 27:6771-6780.

44. Demars M, Hu YS, Gadadhar A, Lazarov O: Impaired neurogenesis is an early event in the etiology of familial Alzheimer's disease in transgenic mice. J Neurosci Res 2010, 88:2103-2117.

45. Rodriguez JJ, Jones VC, Tabuchi M, Allan SM, Knight EM, LaFerla FM, Oddo S, Verkhratsky A: Impaired adult neurogenesis in the dentate gyrus of a triple transgenic mouse model of Alzheimer's disease. PLOS One 2008, 3:e2935.

46. Jin K, Galvan V, Xie L, Mao XO, Gorostiza OF, Bredesen DE, Greenberg DA: Enhanced neurogenesis in Alzheimer's disease transgenic (PDGF-APPSW, Ind) mice. Proc Natl Acad Sci USA 2004, 101:13363-13367.

47. Lopez-Toledano MA, Shelanski ML: Increased neurogenesis in young transgenic mice overexpressing human $\operatorname{APP}(S w$, Ind). J Alzheimers Dis 2007, 12:229-240.

48. Sun B, Halabisky B, Zhou Y, Palop JJ, Yu G, Mucke L, Gan L: Imbalance between GABAergic and Glutamatergic Transmission Impairs Adult Neurogenesis in an Animal Model of Alzheimer's Disease. Cell Stem Cell 2009, 5:624-633.

49. Chen Q, Nakajima A, Choi SH, Xiong X, Sisodia SS, Tang YP: Adult neurogenesis is functionally associated with AD-like neurodegeneration. Neurobiol Dis 2008, 29:316-326.

50. Ashe KH: Learning and memory in transgenic mice modeling Alzheimer's disease. Learn Mem 2001, 8:301-308.

51. Jin K, Peel AL, Mao XO, Xie L, Cottrell BA, Henshall DC, Greenberg DA: Increased hippocampal neurogenesis in Alzheimer's disease. Proc Natl Acad Sci USA 2004, 101:343-347.

52. Boekhoorn $\mathrm{K}$, Joels $\mathrm{M}$, Lucassen $\mathrm{PJ}$ : Increased proliferation reflects glial and vascular-associated changes, but not neurogenesis in the presenile Alzheimer hippocampus. Neurobiol Dis 2006, 24:1-14.

53. Crews L, Adame A, Patrick C, Delaney A, Pham E, Rockenstein E, Hansen L, Masliah E: Increased BMP6 levels in the brains of Alzheimer's disease patients and APP transgenic mice are accompanied by impaired neurogenesis. J Neurosci 2010, 30:12252-12262.

54. Costa DA, Cracchiolo JR, Bachstetter AD, Hughes TF, Bales KR, Paul SM, Mervis RF, Arendash GW, Potter H: Enrichment improves cognition in $A D$ mice by amyloid-related and unrelated mechanisms. Neurobiol Aging 2007, 28:831-844.

55. Nichol KE, Parachikova Al, Cotman CW: Three weeks of running wheel exposure improves cognitive performance in the aged Tg2576 mouse. Behav Brain Res 2007, 184:124-132.

56. Nichol K, Deeny SP, Seif J, Camaclang K, Cotman CW: Exercise improves cognition and hippocampal plasticity in APOE epsilon4 mice. Alzheimers Dement 2009, 5:287-294.

57. Hu YS, Xu P, Pigino G, Brady ST, Larson J, Lazarov O: Complex environment experience rescues impaired neurogenesis, enhances synaptic plasticity, and attenuates neuropathology in familial Alzheimer's disease-linked APPswe/PS1DeltaE9 mice. Faseb J 2010, 24:1667-1681.

58. Lazarov O, Robinson J, Tang YP, Hairston IS, Korade-Mirnics Z, Lee VM, Hersh LB, Sapolsky RM, Mirnics K, Sisodia SS: Environmental enrichment reduces Abeta levels and amyloid deposition in transgenic mice. Cell 2005, 120:701-713. 
59. Mirochnic S, Wolf S, Staufenbiel M, Kempermann G: Age effects on the regulation of adult hippocampal neurogenesis by physical activity and environmental enrichment in the APP23 mouse model of Alzheimer disease. Hippocampus 2009, 19:1008-1018.

60. Wolf SA, Kronenberg G, Lehmann K, Blankenship A, Overall R, Staufenbiel M, Kempermann G: Cognitive and physical activity differently modulate disease progression in the amyloid precursor protein (APP)-23 model of Alzheimer's disease. Biol Psychiatry 2006, 60:1314-1323.

61. Feng R, Rampon C, Tang YP, Shrom D, Jin J, Kyin M, Sopher B, Miller MW, Ware $C B$, Martin GM, et al: Deficient neurogenesis in forebrain-specific presenilin-1 knockout mice is associated with reduced clearance of hippocampal memory traces. Neuron 2001, 32:911-926.

62. Levi O, Michaelson DM: Environmental enrichment stimulates neurogenesis in apolipoprotein E3 and neuronal apoptosis in apolipoprotein E4 transgenic mice. J Neurochem 2007, 100:202-210.

doi:10.1186/1750-1326-6-85

Cite this article as: $\mathrm{Mu}$ and Gage: Adult hippocampal neurogenesis and its role in Alzheimer's disease. Molecular Neurodegeneration 2011 6:85.

\section{Submit your next manuscript to BioMed Central} and take full advantage of:

- Convenient online submission

- Thorough peer review

- No space constraints or color figure charges

- Immediate publication on acceptance

- Inclusion in PubMed, CAS, Scopus and Google Scholar

- Research which is freely available for redistribution

Submit your manuscript at www.biomedcentral.com/submit 